TAPROBANICA, ISSN 1800-427X. April, 2011. Vol. 03, No. 01: pp. 5-10.

(C) Taprobanica Private Limited, Jl. Kuricang 18 Gd.9 No.47, Ciputat 15412, Tangerang, Indonesia.

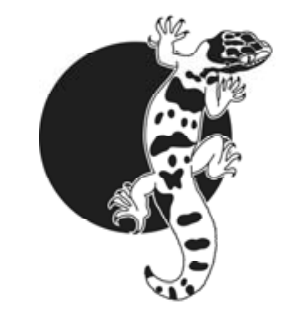

\title{
REPORT OF SOME NOTEWORTHY SPECIMENS AND SPECIES OF HERPETOFAUNA FROM SOUTH-EAST INDIA
}

\author{
S. R. Ganesh ${ }^{1,2}$ and S. R. Chandramouli ${ }^{1}$
}

\footnotetext{
${ }^{1}$ Department of Zoology, Division of Wildlife Biology, A.V.C College, Mannampandal, Mayiladuthurai-609 305, Tamil Nadu, India

${ }^{2}$ Chennai Snake Park, Rajbhavan post, Chennai - 600 020, Tamil Nadu, India

E-mail: snakeranglerr@gmail.com
}

\begin{abstract}
We report abnormal individuals of Ramanella variegata, Lycodon aulicus (sensu lato), Bungarus caeruleus which exhibited variation from the 'typical morphs' of their respective species. Also we report a rarely recorded species Polypedates cf. leucomystax (from south India), from the Mannampandal area of Tamil Nadu. These observations based on voucher photographs are presented for the first time.
\end{abstract}

Keywords: Morph, aberration, variation, phenotypic plasticity, polymorphism

\section{Introduction}

The Coromandel Coast of India was one of the first areas in south Asia where herpetological investigations began, dating back to Russell (1796, 1801). Several species have their type localities in 'Tranquebar' (now Tarangambadi), Pondicherry, 'Madras' (now Chennai) and 'Vizagapatam' (now Vishakapatnam), located in this part of India. The herpetofauna of Mannampandal village $\left(11^{\circ} 09^{\prime} \mathrm{N}\right.$ 079 68’ E; $19 \mathrm{~m}$ a.s.l.) in Mayiladuthurai Taluk, Nagapattinam District, ca. $28 \mathrm{~km}$ west off the historical place Tranquebar has been briefly discussed (Kannan et al., 1994; Ganesh \& Chandramouli, 2007). In this paper we report on certain unique specimens and species of herpetofauna from this area, which are noteworthy in terms of some of their hitherto unknown natural history traits.

\section{Materials and Methods}

These observations were made by random and/or opportunistic sightings between July 2006 and November 2008 in and around Anbanadhapuram Vahaira Charity (A.V.C) College campus. Animals seen were diagnosed, measured and photographed in-situ using Canon Powershot A640 and Canon EOS 400D model cameras. Values of a character presented for more than one individual are separated by a comma. Altitude was determined by 
Garmin 12 channel Global Positioning System readings taken at the locality. Syntopic conspecifics observed were also used for comparison, in addition to published keys, so as to determine any possible patterns of geographically correlated variance if present. However we omitted all data that did not deviate from literature, unless strongly needed, as a backup for species identity.

\section{Observations and Discussion Ramanella variegata (Stoliczka, 1872)}

An adult (Fig.1) sighted on 23/10/07 on tar road, during a rainy night. Dorsum plain grayish brown all over without any visible markings or patterns; supraocular area bluish, labials and gular bluish grey, dorsal parts of fore and hindlimbs pale white, with islets of dark grayish brown, best visible in femur and humerus; venter pinkish white, iris and pupil black and indistinguishable.

The usual colouration of this species, which is the only Ramanella distributed in the southern Indian plains; is olive brown above, finely marbled with yellow or cream, underside white, sometimes marked with brown on the throat and sides (Biju, 2001; Daniels, 2005; Dutta, 1997; Dutta \& Manamendra-Arachchi, 1996). The specific epithet 'variegata' and its common English name 'marbled' narrow mouthed frog are indicative of the variegated / marbled pattern of its dorsum. Uniform grey colouration in this species is hitherto unreported in the literature.

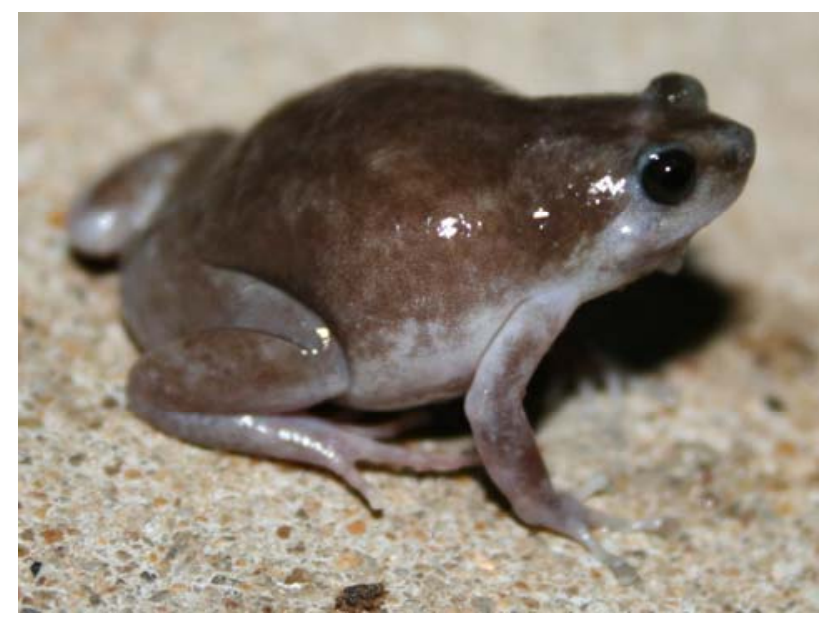

Fig. 1: Ramanella variegata

Polypedates cf. leucomystax (Gravenhorst, 1829)

Two adults (Fig. 2) sighted on 29/10/07 and 28/9/08 on shrubs at night. Dorsum yellowish brown with four darker stripes extending from postnasal, the inner two stripes being paravertebral and the outer two being dorsolateral, the outer and the inner stripes converge at the supraocular region, from where they divide posteriorly to pass through the temporal area and extend to the cloaca, the outer stripes being broadest at mid-torso, exactly at the articulation of the hindlimb with the trunk; postocular region bluish, infralabial and gular surfaces off-white, limbs dorsally cross-barred with darker shades, best visible on the proximal elements of the limbs; venter pinkish white, iris golden brown, pupil horizontal; snout-vent length 20.0, 50.0; axilla-groin distance: $8.3,20.7$; head length 9.0, 22.6; head width 7.0, 17.6; snout length 3.0, 7.6; eye diameter 1.3, 3.3; tympanum diameter 1.3, 3.3; internarial distance 1.9, 4.7; interorbital distance 3.0, 7.5.

We observed several Polypedates maculatus (Gray, 1834) that matched the descriptions in literature (Dutta, 1997; Dutta \& Manamendra-Arachchi, 1996) but these two individuals are certainly not $P$. maculatus as there is no dorsally 'striped' pattern present in $P$. maculatus, whose specific epithet means 'spotted' (Dutta \& Manamendra-Arachchi, 1996). Dutta (1997) stated that P. leucomystax is widely distributed in most parts of Southeast Asia and different colour morphs led to the erection of subspecies from different geographic localities. It differs from its closely allied congener $P$. maculatus by an osteological character 'parieto-squamosal arch bone' which is evident at normal resting posture in $P$. lecomystax but not in $P$. maculatus (Daniel, 2002; Daniels, 2005; Dutta, 1997).

Dutta (1997) remarked that some earlier authors considered P. maculatus and leucomystax to be subspecies and the occurrence of $P$. leucomystax in Sri Lanka is erroneous and in Karnataka, south India is doubtful. The report from the Western Ghats of Karnataka was once considered authentic and then 'changed' to doubtful (Daniels, 1997, 2000 \& 2005). Biju (2001) and Daniel (2002) deny its presence in south India. Banerjee \& Deuti (2006) give its English name as 'four-lined' tree frog (vs. 'six-lined' tree frog fide Daniels, 2005), which is consistent with its former, specific epithet 'quadrilineata' [(sensu Boie, 1835) see Dutta, 1997].

Soud \& Das (2005) state P. leucomystax to be common in low lands and urban areas with water and prolific vegetation, in the Bongaigon District of Assam State. Hussain et al. (1999) mention its distribution in Northeast India up to an elevation of $300 \mathrm{~m}$ asl. Deuti (1997) reports a range extension of this species from Sikkim, West Bengal, Assam, 
Meghalaya, Arunachal Pradesh, Manipur and also curiously from Gujarat and Madhya Pradesh. Rao et al. (2005) mentions its occurrence in Nallamalai hills, a part of the Eastern Ghats of Andhra Pradesh in south India, with photographic evidence. Given this scenario, it can no longer be considered as a mesic forest habitat specialist, but is rather a eurytopic species occurring in plains and anthropogenic habitats as well. Since $P$. leucomystax in itself is a species-complex containing sympatric morphotypes (Narins et al., 1998), we refer our specimens to Polypedates cf. leucomystax, based on evident parietosquamosal arch bone visible at rest and the 'striped' dorsum.

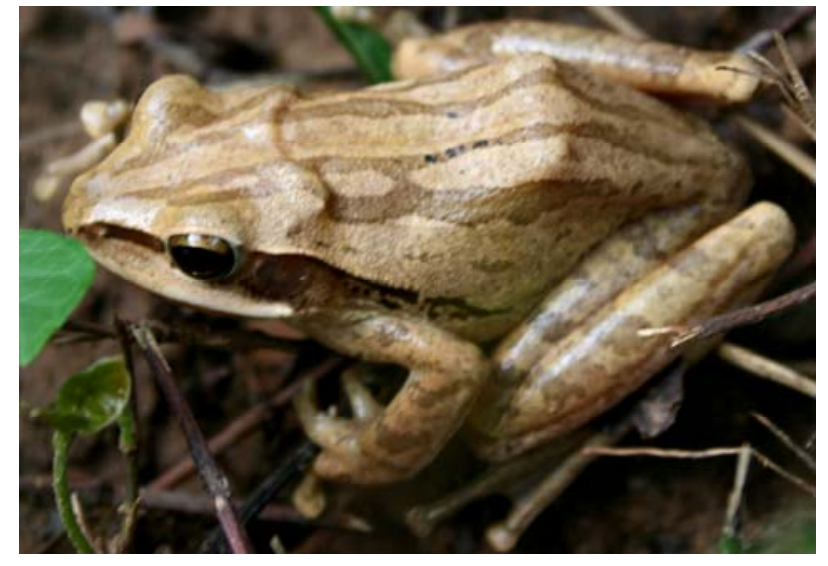

Fig. 02: Polypedates cf. leucomystax

\section{Lycodon aulicus (Linnaeus, 1758) sensu lato}

Table 1: Comparison of meristic, morphologic and metric characters between 'typical' and 'aberrant' morphs of syntopic adult males of Lycodon aulicus from Mannampandal.

\begin{tabular}{|c|c|c|c|}
\hline No & Characters & Morph 1 & Morph 2 \\
\hline 1 & Scalerows (smooth) & $17: 17: 15$ & $17: 17: 15$ \\
\hline 2 & Apical pits & towards centre of tip & towards upside of tip \\
\hline 3 & Supralabials (those touching eye) & $9(3,4,5)$ & $9,11(3,4,5)$ \\
\hline 4 & Infralabials (those touching genials) & $9(6,7)$ & $9,10(5)$ \\
\hline 5 & Loreal (horizontally elongate) & 1 & 1 \\
\hline 6 & Temporal & $2+3$ & $2+2$ \\
\hline 7 & Preocular & 1 & 1 \\
\hline 8 & Postocular & 2 & 2 \\
\hline 9 & Preventrals & 3 & 3 \\
\hline 10 & Linguals & 5 & 4 \\
\hline 11 & Ventrals (strongly angulate laterally) & 218 & 199 \\
\hline 12 & Anals & 2 & 2 \\
\hline 13 & Subcaudals (divided) + terminal scale & 68 pairs +1 & 68 pairs +1 \\
\hline 14 & Nuchal mark & inverted V shape & V shape \\
\hline 15 & Band structure & parallel & diverging \\
\hline 16 & Band pattern & patterned interiorly & plain interiorly \\
\hline 17 & Band extent & visible dorsally only & visible laterally also \\
\hline 18 & Head length & 21.3 & 25 \\
\hline 19 & Snout length & 7 & 3.3 \\
\hline 20 & Head width (maximum) & 13 & 14.5 \\
\hline 21 & Head width (eye level) & 10.3 & 11 \\
\hline 22 & Neck width & 10.6 & 10.6 \\
\hline 23 & Eye diameter & 3.6 & 1.3 \\
\hline 24 & Loreal length & 3 & 2.5 \\
\hline 25 & Lower eye margin-lip distance & 2 & 1.3 \\
\hline 26 & Inter orbital distance & 5.9 & 3.3 \\
\hline 27 & Position of first band (respect to ventrals) & 9 & 0 \\
\hline 28 & Scales between parietal and first band & 11 & 2 \\
\hline 29 & Head length: snout length & 3.04 & 7.37 \\
\hline
\end{tabular}




\begin{tabular}{c|l|c|c}
30 & Head length: maximum head width & 1.63 & 1.72 \\
\hline 31 & Max. head width: neck width & 1.22 & 1.36 \\
\hline 32 & Head width (eye level): neck width & 0.97 & 1.03 \\
\hline 33 & Eye diameter: lower eye margin-lip distance & 1.8 & 1 \\
\hline 34 & Loreal length: eye diameter & 1.2 & 1.92 \\
\hline 35 & Snout length: Interorbital distance & 1.18 & 1 \\
\hline
\end{tabular}

An adult male, (Figs. $3 \& 4$ ) one each of the two morphs, on tarred road and brick pile (respectively), at night. Comparison of characters 2, 14-17 and 2735 in the above table reveals considerable differences in cephalic morphometry, general habitus and colouration between these two morphs. There is no literature report about this phenomenon (Sharma, 2003; Smith, 1943; Whitaker, 1978; Whitaker \& Captain, 2004), except Daniel (2002) who gives drawings [from Wall] of its various colour morphs. Smith (1943) in his line drawings, Daniel (2002), Whitaker \& Captain (2004) and Goonewardene et al. (2006) in their photographs depict morph 1 with thick head and first band in inverted-V shape just behind parietals (i.e., on the head and well before the neck). Das (2002) Das \& de Silva (2005) and Whitaker (1978) depict morph 2 , with the first band in $\mathrm{V}$ shape, well off the parietals, but near the neck. Rao et al. (2005) from Nallamalai hills depict morph 2 as L. aulicus and morph 1 (incorrectly) as L. travancoricus, which apart from our record, are another proof for syntopy between these two morphs. Though morph 2 superficially resembles L. osmanhilli (Taylor, 1950) of Sri Lanka, it differs from the latter by the character preocular contacting frontal (vs. not in contact, in L. osmanhilli) (de Silva, 1980). Therefore, we doubt that the Lycodon aulicus s. lat. complex is yet taxonomically unresolved. We have given the differences between merely a single representative from each of the two morphs, but this is evident enough to distinguish them. In the live individual of morph 1, we counted 218 ventrals excluding preventrals (vs. < 214 in Smith, 1943; Whitaker \& Captain, 2004) which imply that literature defining this species cannot be considered as fully comprehensive. Considering the variations shown herein and the rich, subjective synonyms originating from places far and wide, we strongly suggest that more detailed studies needed to be undertaken to resolve the taxonomy of $L$. aulicus (sensu lato). Similar works involving subtle variation in colouration and morphometry led to the resurrection of Dendrophis chairecacos Boie, 1827 and Dipsas schokari Kuhl, 1820 from the synonymy of Dendrelaphis tristis (Daudin, 1803) sensu Smith (1943) (see Van Rooijen \& Vogel,
2008 \& '2009’ 2010).

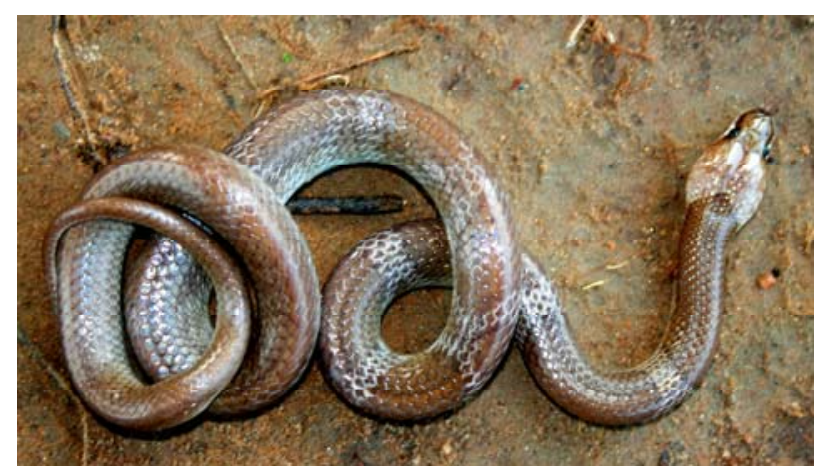

Fig. 3: Lycodon aulicus morph 1

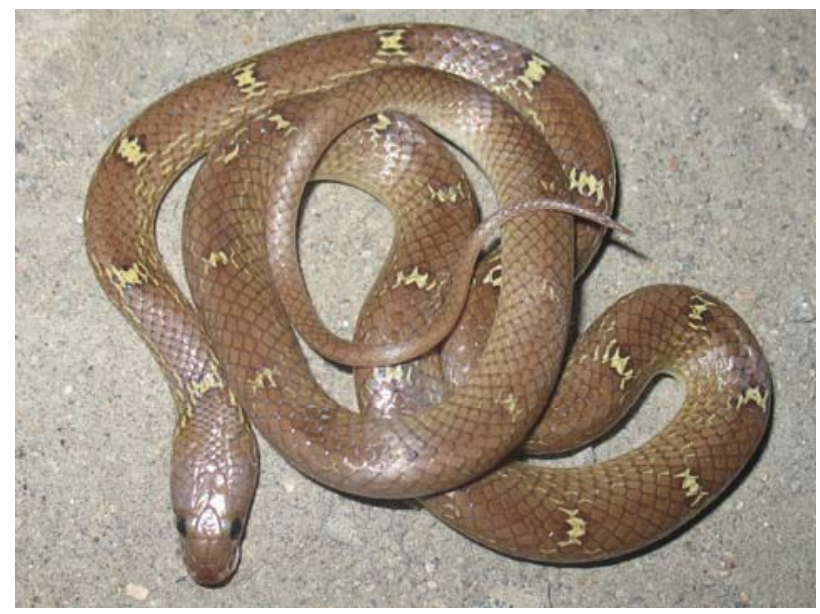

Fig. 4: Lycodon cf. aulicus morph 2

\section{Bungarus caeruleus (Schneider, 1802)}

An adult (Fig. 5), dead individual measuring 780 mm observed at night on 23/8/07 on a tarred road during a rainy night. Dorsally grayish black without any white cross bands and was without even a speck of white on the dorsum; supralabials, penultimate costals and venter white. Scalerows (smooth) 15:15:15; ventrals (not angulate laterally) 202; subcaudals (undivided) 40; anal 1; supralabials (touching eye) $7(3,4)$; preocular 1 ; postoculars 2 ; temporals $1+2$.

Scalation of our individual agrees with literature (Russell, 1796; Whitaker \& Captain, 2004) accounts of Bungarus caeruleus. It is certainly not B. niger Wall, 1908 as the distribution records are well off the mark and $B$. niger has higher ventral 
and subcaudal counts (ventrals: 216-231; subcaudals: 47-57) than B. caeruleus, (see Smith, 1943; Whitaker \& Captain, 2004).

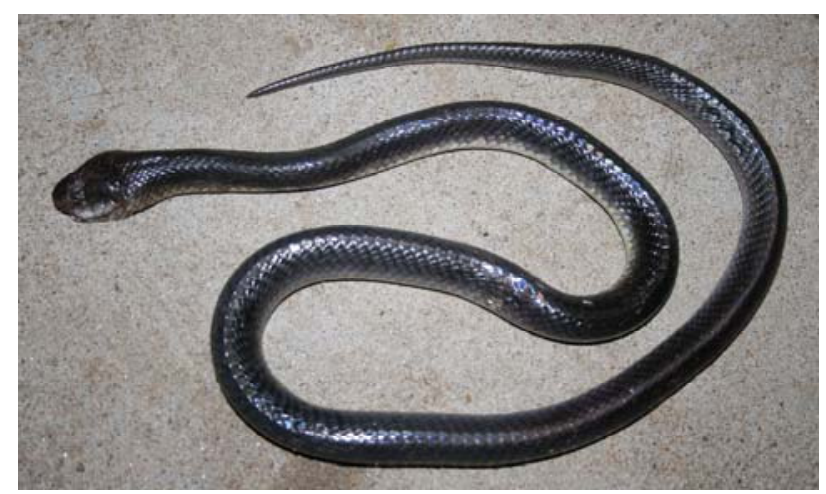

Fig. 5: Bungarus caeruleus

The aberrant individual was not observed to be in the cycle of ecdysis, which can render body patterns unclear (Whitaker \& Captain, 2004). It was an adult, $780 \mathrm{~mm}$ long, which is noteworthy here as young snakes are known to have much more intense patterns than adults, as seen in Eryx johnii, Macrophisthodon plumbicolor, Argyrogena fasciolatus, Ophiophagus hannah and Bungarus caeruleus (see Smith, 1943; Whitaker \& Captain, 2004). Full grown individuals of this species are known to become dull gray in colour without any banded pattern (Anslem de Silva pers. comm., March, 2010). The total length of our individual was $780 \mathrm{~mm}$, which is close to the average length (1000 mm) and is nowhere near the maximum length (1750 mm) (Whitaker \& Captain, 2004). Moreover, B. caeruleus exhibits a peculiar phenomenon of colour variation with respect to geography. In India, the south-west coast and the south-east coast populations of $B$. caeruleus differ in colouration, with the west coast kraits being more evidently banded than those of the east (Das, 2002). All conspecifics (both adults and juveniles) observed from the present area, were typically banded (pers. obs.). Dravidamani et al. (2006) examined up to 200 individuals, but failed to record any aberrations. Kuch (1991), Whitaker (1969) and Vogel \& Chanhome (2006) report of banded snakes like Bungarus fasciatus and Boiga dendrophila melanota exhibiting aberrant pattern, notably stripes instead of the usual banded pattern (see Whitaker \& Captain, 2004; Smith, 1943; Vogel \& Chanhome, 2006). Kuch (1991) stated that he provisionally preferred to regard longitudinally striped aberrant snakes to be individual mutations rather than a geographically correlated phenotype. While Whitaker (1969) commented that the female and all six juveniles were striped, with just two bands on the tail and in scalation they did not differ from Bungarus fasciatus. Vogel \& Chanhome (2006) remarked that such phenomenon of parent and offspring exhibiting similar, consistent variation was associated with low incubation temperatures or a dominant recessive genetic disposition. Since we observed only one individual with this sort of aberration, we are presently unable to comment on the reason for the same.

\section{Remarks}

Our observations indicate the lacuna present in the herpetological community of this highly anthropogenic, non-forested alluvial plains country, which is no more than a matrix of plantations and rivulets, despite the fact that many of the species reported here are widespread in the country and are often encountered in the wild. Phenotypic plasticity has been a very interesting and often highly influential factor in contributing to polymorphism. Prince et al. (2003) state that "genotype + environment + random variation $\rightarrow$ phenotype", which are aberrant individuals that differ from normal conspecifics in any noticeable way including morphology, physiology and behaviour. Very little published information is available on phenotypic plasticity in Indian herpetofauna.

\section{Acknowledgements}

We thank our college's Zoology Department and Men's Hostel for providing the necessary infrastructure; Agumbe Rainforest Research Station, Chennai Snake Park and Madras Crocodile Bank for access to their libraries; herpetologists, Anslem de Silva, Biju Sathyabama Das, Aaron Bauer, Romulus Earl Whitaker and Ruchira Somaweera for their advice, suggestions and literature.

\section{Literature Cited}

Banerjee, A. and K. Deuti, 2006. Breeding record of four-lined tree frog (Polypedates leucomystax) (Gravenhorst, 1829) at Rajpur, South 24 Praganas District, West Bengal. Cobra, 64: 16-17.

Biju, S. D., 2001. A Synopsis to the frog fauna of Western Ghats, India. Indian Society for Conservation Biology. Occasional Publication, (1): 1-24.

Daniel, J. C., 2002. The Book of Indian Reptiles and Amphibians. Bombay Natural History Society, Oxford University Press, Mumbai: 238.

Daniels, R. J. R. 1997. A Field Guide to the frogs and toads of the Western Ghats. Part III. Cobra, 29:1-13. 
Daniels, R. J. R., 2000. Reptiles and amphibians of Karnataka. Cobra, 42: 1-11.

Daniels, R. J. R., 2005. Amphibians of Peninsular India. Universities Press, Hyderabad, India: 286.

Das, I., 2002. A Photographic Guide to Snakes and other Reptiles of India. New Holland publications, London, UK: 144

Das, I. and A. de Silva, 2005. A Photographic Guide to Snakes and other Reptiles of Sri Lanka. New Holland Publications, London, UK 144.

De Silva, P. H. D. H., 1980. Snake fauna of Sri Lanka, with special reference to skull, dentition and venoms in snakes. National Museum of Sri Lanka publication. Kandy, Sri Lanka: 472.

Deuti, K., 1997. Range extension of some Indian Amphibians. Cobra, 29: 19-28.

Dravidamani, S., P. Kannan, V. Kalaiarasan, R. Deepika, J. Gitanjali, J. R. Moss and S. Rajan, 2006. Studies on the size composition and morphometry of common krait Bungarus caeruleus (Schneider, 1801) at the Irula Snake Catchers' Industrial Co-operative Society, Vadanemmeli, Kanchipuram district, Tamil Nadu. Cobra, 64: 1-7.

Dutta, S. K. and K. Manamendra-Arachchi, 1996. The Amphibian fauna of Sri Lanka. Wildlife Heritage Trust, Sri Lanka: 230.

Dutta, S. K., 1997. The Amphibians of India and Sri Lanka. Odyssey Book House, Orissa, India: 342.

Ganesh, S. R. and S. R. Chandramouli, 2007. A study of herpetofaunal community in Mannampandal, Nagapatinam District, Tamil Nadu. Cobra, 1 (4): 33-43.

Goonewardene, S., J. S. Drake and A. de Silva, 2006. The Herpetofauna of the Knuckles Range. Amphibian and Reptile Research Organization of Sri Lanka: 208.

Hussain, B., N. Choudry and S. Senguptha, 1999. A note on the reproduction in Polypedates leucomystax (Gravenhorst, 1829). Hamadryad, 24 (1): 44-45.

Kannan, P, C. Sankaravadivelu and V. Kalaiarasan, 1994. Herpetofaunal assemblage in Mayiladuthurai area: A conservational approach. Cobra, (18): 1-15.

Kuch, U., 1991. Abnormal colouration in the banded krait Bungarus fasciatus (Schneider, 1801). The Snake, 23: 25-28.

Narins, P. M, A. S. Feng, H. Yong and J. ChristensenDalsgaard, 1998. Morphological, behavioral and genetic divergence of sympatric morphotypes of the tree frog Polypedates leucomystax in Peninsular Malaysia. Herpetologica, 54 (2): 129-142.
Prince, T. D., A. Quarnstrom and D. E. Irwin, 2003. The role of phenotypic plasticity in driving evolution. Proceedings of Biological Sciences, 270: 1433-1440.

Rao, T., H. V. Ghate, M. Sudhakar, S. M. M. Javed, and S. R. Krishna, 2005. Herpetofauna of Nallamalai Hills, with eleven new records from the region, including ten new records from Andhra Pradesh. Zoo's Print Journal, 20 (1): 1737-1740.

Russell, P., 1796. An account of Indian serpents collected on the coast of Coromandel, containing descriptions and drawings of each species together with several experiments and remarks on their poisons. Shakespeare Press, London: 49+43 pls.

Russell, P., 1801. Continuation of an account of Indian Serpents containing descriptions and figures from specimens and drawings, transmitted from various parts of India. Shakespeare Press, London: 45+39 pls.

Sharma, R. C., 2003. Handbook - Indian Snakes. Zoological Survey of India, Kolkata, India: 292.

Smith, M. A., 1943. Fauna of British India, including Ceylon and Burma. Vol-III Serpentes. Taylor \& Francis publications, London : 583.

Soud, R. and R. Das, 2005. Some observations on Polypedates leucomystax (Gravenhorst, 1829) (Anura: Rhacophoridae) from urban areas. Cobra, 62: 29-30.

Van Rooijen, J. and G. Vogel, 2008. An investigation into the taxonomy of Dendrelaphis tristis (Daudin, 1803): revalidation of Dipsas schokari Khul, 1820 (Serpentes, Colubridae). Contributions to Zoology, 77: 33-43.

Van Rooijen, J. and G. Vogel, 2009 '2010'. A multivariate investigation into the population systematics of Dendrelaphis tristis (Daudin, 1803) and Dendrelaphis schokari (Khul, 1820): revalidation of Dendrophis chairecacos Boie, 1827 (Srepentes, Colubridae). The Herpetological Journal, 19: 193-200.

Vogel, G. and L. Chanhome, 2006. On two remarkable colour variants in Boiga dendrophila melanota (Boulenger, 1896) (Serpentes: Colubridae). Hamadryad, 30 (1\&2): 199-203.

Whitaker, R., 1969. Abnormal colouration in the Banded Krait (Bungarus fasciatus). Journal of the Bombay Natural History Society, 66 (1): 184-185.

Whitaker, R., 1978. Common Indian Snakes - A Field Guide. MacMillan Press, New Delhi, India: 154.

Whitaker, R. and A. Captain, 2004. Snakes of India The Field Guide. Draco Books, Chengalpet, South India: 481. 